\title{
The effect of concentration of ab mix and zpt solutions on the growth and production of mustard plants (Brassica juncea L.) in hydroponic wick systems
}

\author{
Muhammad Reza Subakti ${ }^{1}$, Nurhayati ${ }^{2 *}$, and Murni Sari Rahayu ${ }^{3}$ \\ ${ }^{1}$ Student Department of Agrotechnology, Faculty of Agriculture, Universitas Islam Sumatera Utara, Address Karya \\ Wisata Gedung Johor, Medan 20144, Indonesia \\ ${ }^{2}$ Department of Agrotechnology, Faculty of Agriculture, Universitas Islam Sumatera Utara, Address Karya Wisata Gedung Johor, \\ Medan 20144, Indonesia \\ ${ }^{3}$ Department of Agrotechnology, Faculty of Agriculture, Universitas Islam Sumatera Utara, Address Karya Wisata Gedung Johor, \\ Medan 20144, Indonesia
}

\begin{abstract}
This research was implemented in the greenhouse at the Experimental Garden of the Faculty of Agriculture Universitas Islam Sumatera Utara, Sub-distric Gedung Johor, Medan Johor District, Medan City, North Sumatra Province. This research was implemented from November to December 2020. This study aims to determine the effect of concentration of AB Mix and ZPT solutions on the growth and production of mustard greens. This study used a completely randomized design (CRD) with two treatment factors the concentration of AB Mix solution and ZPT application. The first factors, the concentration of $\mathrm{AB}$ Mix solution consisting of 3 levels: $\mathrm{K}_{0}=$ control, $\mathrm{K}_{1}=550 \mathrm{ppm}, \mathrm{K}_{2}=1100 \mathrm{ppm}$. The second factor was giving $\mathrm{ZPT}$ the earliest in 3 levels: $\mathrm{Z}_{0}=$ control, $\mathrm{Z}_{1}=0.5 \mathrm{ml}, \mathrm{Z}_{2}=1 \mathrm{ml}$. The parameters observed were plant height, number of leaves, leaf length, leaf width, wet weight and dry weight. Its is know from the results concentrations of AB Mix solution significantly affected plant height, number of leaves, leaf length, leaf width, wet weight and dry weight. Giving of ZPT had a significant effect on leaf width but had no significant effect on plant height, number of leaves, leaf length, wet weight and dry weight. The interaction of AB Mix solution concentration and ZPT giving had no significant effect on the growth and production of mustard greens.
\end{abstract}

\section{Preliminary}

Vegetables are plant commodities that are able to contribute to national development in order to welfare the community, such as fulfilling community nutrition as a complement to the four healthy five perfect foods, also very potential and prospective to be cultivated because cultivation methods tend to be easy and simple. One of the easiest vegetables to cultivate is mustard [1].

Green mustard (Brassica juncea L.) is one of the most important vegetable commodities in the world. Although green mustard is not native to Indonesia, the development of this agribusiness and agro-industry patterned crop commodity can be categorized as a source of income in the agricultural sector in Indonesia [1].

Green mustard plants are known to have high economic value because this vegetable is one of Indonesia's main export commodities. However, until now, mustard plants production has not been able to meet the needs of domestic and foreign markets. This is because the average national mustard plants production is still very low. The potential yield of mustard greens can reach 40 tons/ha, while the average yield of mustard plant in Indonesia is 9 tons/ha [2].
The low production of mustard greens in Indonesia can be caused by several reasons, such as the application of cultivation technology that is still simple, or because the land for growing crops is decreasing. As is known, today's industrial development is progressing rapidly. These development have shifted a lot of agricultural land, especially in urban areas. As a result, agricultural land is getting smaller. To overcome this, various ways can be taken to increase plant productivity. In this way, it is hoped that from a narrow area, large production can be produced [3].

Hydroponics comes from the Greek, namely hydro which means water and ponos which means power. Hydroponics is also known as soilless culture or plant cultivation without soil. So hydroponics is a method of growing crops without using soil media, but using a nutrient solution of minerals or other materials containing nutrients such as coconut fiber, mineral fiber, sand, broken bricks, sawdust and others as a substitute for soil media. Hydroponic plants can be done on a small scale at home as a hobby or on a large scale with commercial purposes [4].

One of the simplest hydroponic systems is the wick system. Hydroponics wicks (wicks) is a simple method by using a wick as a link between nutrients and the roots

* Corresponding author: nurhayatijb@yahoo.co.id 
of the growing media. This hydroponic system is passive, because there are no moving parts in this medium [5].

In the production process, proper planting media and growth regulators are needed to obtain good growth [6]. The use of growth regulators plays a role in increasing the growth and production of vegetable crops. Plant regulatory substances are organic compounds that are not active plant nutrients in small amounts that are synthesized in certain parts of the plant and are generally transported to other parts of the plant, where these growth regulators cause biochemical, physiological and morphological responses [7].

The purpose of the study was to determine the right concentration of nutrients and the right level of ZPT in increasing the growth and production of mustard greens (Brassica juncue L.) in the Hydroponic Wick system.

\section{Materials and Methods}

\subsection{Place and Time Research}

This research was conducted at the Experimental Garden Greenhouse, Faculty of Agriculture, Islamic University of North Sumatra, Jalan Karya Wisata, Gedung Johor Village, Medan Johor District, Medan City, North Sumatra Province. This research was carried out in October until Nopember 2020.

\subsection{Materials and Tools}

The materials used in this study were green mustard seeds as planting material, Styrofoam used as a planting medium and a place to accommodate nutrient water solutions, a netpot for placing mustard plants, rockwool as a planting medium for mustard plants, seed seeding tanks, AB mix nutrient solution. Atonic as material to be used for ZPT solution.

The tools used in this study are $\mathrm{PH}$ measuring devices that will be used to measure the $\mathrm{PH}$ of water, TDS tools that will be used to measure the concentration of nutrient solutions, digital scales used to weigh the wet and dry weight of mustard plants, oven to dry mustard plants, drill to make planting holes in Styrofoam boxes, markers used to mark the location of planting holes, gauze, tape measure or rollers to measure plant spacing and to measure plant parameters, buckets, gembors or spray guns for watering mustard plants, a $20 \mathrm{ml}$ syringe is used as a substitute for a measuring cup that will be used as a measure of the AB MIX and ZPT solutions that will be used.

\subsection{Research Methods}

The design model used in this study was a factorial completely randomized design (CRD) consisting of factor I: Concentration of $\mathrm{AB}$ mix solution consisting of 3 levels, namely: $\mathrm{K}_{0}$ : Control, $\mathrm{K}_{1}: 550$ ppm, $\mathrm{K}_{2}: 1100$ ppm and Factor II: Addition ZPT consists of 3 levels, namely: $\mathrm{Z}_{0}$ : Control, $\mathrm{Z}_{1}: 0.5 \mathrm{ml}, \mathrm{Z}_{2}: 1 \mathrm{ml}$. Observation parameters were plant height, number of leaves, leaf length, leaf width, wet weight and dry weight of mustard plants.

Application of Nutrition and ZPT. Provision of nutrients and ZPT is carried out before the plants are transferred to the planting plot, before the nutrients and PGR are entered, first enter the water into the Styrofoam box as much as 8 liters/plot, then after that input the ABmix nutrient solution at a rate of $8 \mathrm{ml} /$ liter of water for $\mathrm{K} 2$ and $4 \mathrm{ml}$ treatment/liters of water for treatment $\mathrm{K} 1$ and ZPT solution with a dose of $1 \mathrm{ml} /$ liters of water for treatment $\mathrm{Z} 2$ and $0.5 \mathrm{ml} /$ liters of water for treatment K1 then mix the solution into a Styrofoam box that already contains water then after that stir and measure whether the content the nutrients entered are in accordance with the doses determined using the TDS tool.

\section{Research Result}

\subsection{Plant Height (cm)}

The results of the analysis of variance show that the concentration of the AB Mix solution had a significant effect. The treatment of giving ZPT and the interaction of the two treatment factors had no significant effect on the height of the mustard plant. The average height of mustard plants is presented in Table 1.

In Table 1 it can be seen that the concentration of the AB Mix solution had a significant effect on the height of the mustard plant. The highest plants were obtained in treatment $\mathrm{K}_{2}(1100 \mathrm{ppm})$ which was $7.18 \mathrm{~cm}$, which was significantly different from treatment $\mathrm{K}_{0}$ (control) which was $5.69 \mathrm{~cm}$, but not significantly different from treatment $\mathrm{K}_{1}(550 \mathrm{ppm})$ which was $6.54 \mathrm{~cm}$.

The relationship between the height of the mustard plant and the concentration of the $\mathrm{AB}$ Mix solution is linear with the equation $=5.725+0.0014 \mathrm{~K}, \mathrm{r}=0.99$. The equation describes a positive linear relationship between the concentration of $\mathrm{AB}$ Mix solution and plant height. Thus, the nutrients contained in the $\mathrm{AB}$ Mix solution have a positive effect on mustard plants, namely being able to trigger vegetative development.

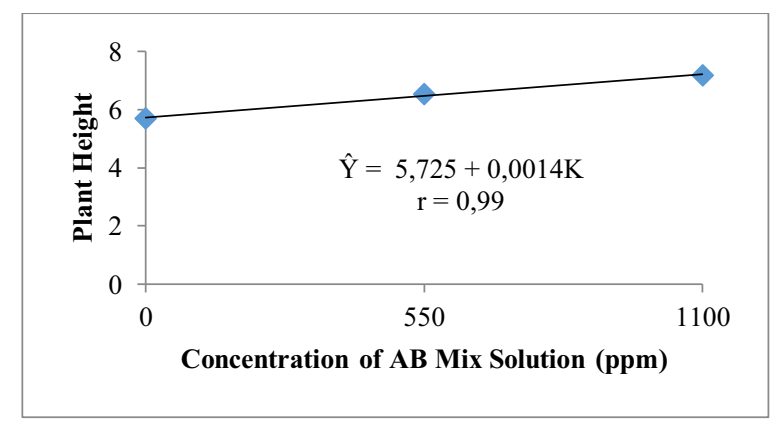

Fig.1. Relationship of Mustard Plant Height (cm) with AB Mix Solution Concentration (ppm)

The provision of ZPT had no significant effect on the height of the mustard plant. The highest plant height was obtained in treatment $Z_{2}(1 \mathrm{ml})$ which was $6.59 \mathrm{~cm}$, followed by treatment $Z_{1}(0.5 \mathrm{ml})$ which was $6.49 \mathrm{~cm}$ and treatment $\mathrm{Z}_{0}$ (control) was $6.32 \mathrm{~cm}$. 


\subsection{Number of Leaves (sheet)}

The results of the analysis of variance show that the concentration of the AB Mix solution had a significant effect. The treatment of giving ZPT and the interaction of the two treatment factors had no significant effect on the number of mustard leaves. The average number of mustard leaves is presented in Table 1 .

In Table 1 it can be seen that the concentration of the AB Mix solution had a significant effect on the number of mustard leaves. The highest number of leaves was obtained in treatment $\mathrm{K}_{2}(1100 \mathrm{ppm})$ which was 9.39 leaves, which was significantly different from treatment $\mathrm{K}_{0}$ (control) which was 8.39 leaves, but not significantly different from treatment $\mathrm{K}_{1}(550 \mathrm{ppm})$ which was 9.00 leaves.

The relationship between the number of mustard leaves and the concentration of the $\mathrm{AB}$ Mix solution is linear with the equation $=8.426+0.0009 \mathrm{~K}, \mathrm{r}=0.99$. Based on these equations, it describes a positive linear relationship between the concentration of $\mathrm{AB}$ Mix solution and the number of leaves. The figure shows that the number of leaves will continue to increase along with the concentration of $\mathrm{AB}$ Mix solution.

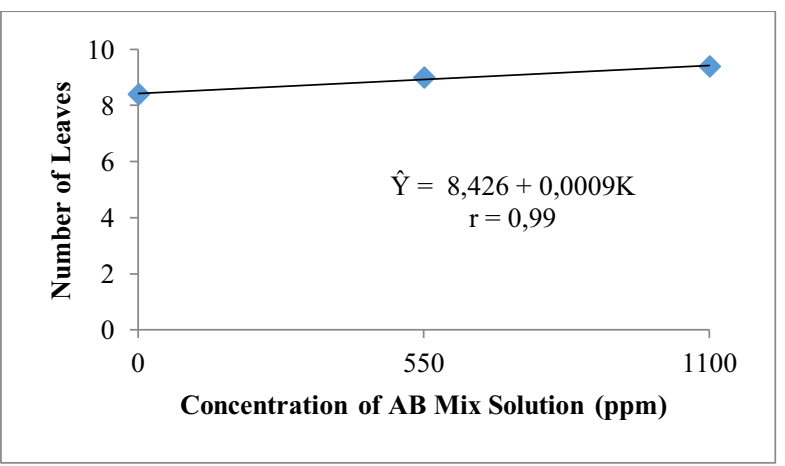

Fig.2. The Relationship between the Number of Mustard Leaves (strands) and the Concentration of AB Mix Solution (ppm)

Giving ZPT had no significant effect on the number of mustard leaves. The highest number of leaves was obtained in treatment $Z_{2}(1 \mathrm{ml})$ with 9.08 leaves, followed by treatment $Z_{1}(0.5 \mathrm{ml})$ with 8.89 leaves and treatment $Z_{0}$ (control) with 8.81 leaves.

\subsection{Leaf Length $(\mathrm{cm})$}

The results of the analysis of variance show that the concentration of the AB Mix solution had a significant effect. The treatment of giving ZPT and the interaction of the two treatment factors had no significant effect on the length of the mustard leaf. The average mustard leaf length is presented in Table 1 .

In Table 1 it can be seen that the concentration of the AB Mix solution had a significant effect on the length of the mustard leaf. The longest leaf length was obtained in treatment $\mathrm{K}_{2}(1100 \mathrm{ppm})$ which was $12.61 \mathrm{~cm}$, which was significantly different from treatment $\mathrm{K}_{0}$ (control) which was $10.68 \mathrm{~cm}$, but not significantly different from treatment $\mathrm{K}_{1}(550 \mathrm{ppm})$ which was $11.71 \mathrm{~cm}$.

The relationship between the length of the mustard leaf and the concentration of the $\mathrm{AB}$ Mix solution is linear with the equation $=10.698+0.0018 \mathrm{~K}, \mathrm{r}=0.99$. This equation illustrates that there is a positive linear relationship between the concentration of $\mathrm{AB}$ Mix solution and leaf length. The higher the concentration of the AB Mix solution, the longer the leaf length.

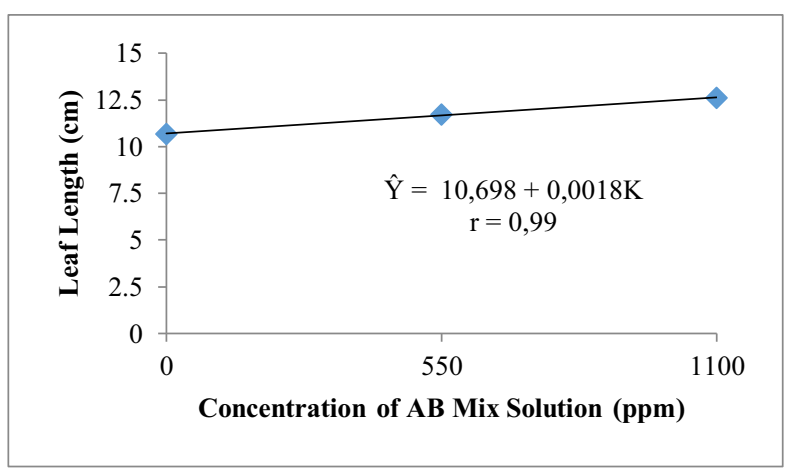

Fig.3. The Relationship of Mustard Leaf Length (cm) with AB Mix Solution Concentration (ppm)

Giving ZPT did not significantly affect the length of mustard leaves. The longest leaf length was obtained in treatment $Z_{2}(1 \mathrm{ml})$ which was $12.19 \mathrm{~cm}$, followed by treatment $Z_{1}(0.5 \mathrm{ml})$ which was $11.78 \mathrm{~cm}$ and treatment $\mathrm{Z}_{0}$ (control) was $11.02 \mathrm{~cm}$.

\subsection{Leaf Width $(\mathrm{cm})$}

The results of the analysis of variance show that the treatment with the concentration of AB Mix solution and the administration of ZPT had a significant effect. The interaction of the two treatment factors had no significant effect on the width of the mustard leaf. The average mustard leaf width is presented in Table 1 .

In Table 1 it can be seen that the concentration of the AB Mix solution had a significant effect on the width of the mustard leaf. The widest leaf width was obtained in treatment $\mathrm{K}_{2}(1100 \mathrm{ppm})$ which was $10.87 \mathrm{~cm}$, which was significantly different from treatment $\mathrm{K}_{0}$ (control) which was $8.46 \mathrm{~cm}$, but not significantly different from treatment $\mathrm{K}_{1}(550 \mathrm{ppm})$ which was $10.43 \mathrm{~cm}$.

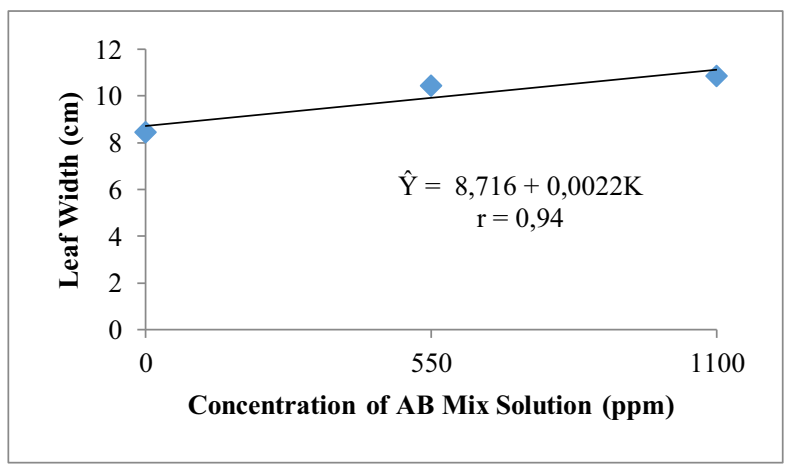

Fig.4. The Relationship of Mustard Leaf Width (cm) with Provision of AB Mix Solution Concentration (ppm)

The relationship between mustard leaf width and the concentration of $\mathrm{AB}$ Mix solution is linear with the equation $=8.716+0.0022 \mathrm{~K}, \mathrm{r}=0.94$. This equation illustrates that there is a positive linear relationship between the concentration of AB Mix solution and leaf 
width. The higher the concentration of the $\mathrm{AB}$ Mix solution, the wider the leaf width.

Giving ZPT significantly affected the width of mustard leaves. The widest leaf width was obtained in treatment $Z_{2}(1 \mathrm{ml})$ which was $10.81 \mathrm{~cm}$, which was significantly different from treatment $Z_{1}(0.5 \mathrm{ml})$ which was $9.58 \mathrm{~cm}$ and treatment $Z_{0}$ (control) was $9.36 \mathrm{~cm}$.

The relationship between mustard leaf width and ZPT concentration was linear with the equation = $9.1917+1.45 \mathrm{Z}, \mathrm{r}=0.93$. This equation illustrates that there is a positive linear relationship between the administration of ZPT concentration and leaf width.

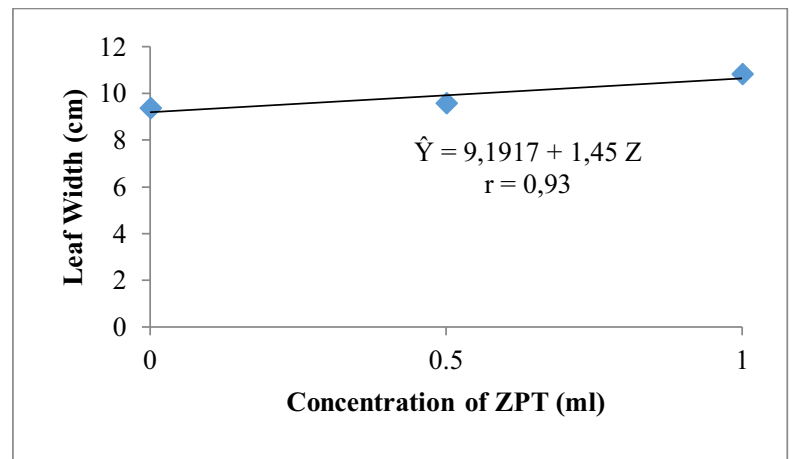

Fig.5. Relationship of Mustard Leaf Width (cm) with ZPT Concentration (ml)

\subsection{Wet Weight (g)}

The results of the analysis of variance show that the concentration of the AB Mix solution had a significant effect. The treatment of giving ZPT and the interaction of the two treatment factors had no significant effect on the wet weight of mustard greens. The average wet weight of mustard greens is presented in Table 1.
In Table 1, it can be seen that the concentration of the AB Mix solution had a significant effect on the wet weight of mustard greens. The heaviest wet weight was obtained in treatment $\mathrm{K}_{2}(1100 \mathrm{ppm})$ which was 159.22 $\mathrm{g}$, which was significantly different from treatment $\mathrm{K}_{0}$ (control) which was $84.89 \mathrm{~g}$ and treatment $\mathrm{K}_{1}(550 \mathrm{ppm})$ which was $125.55 \mathrm{~g}$.

The relationship between the wet weight of mustard greens and the concentration of the $\mathrm{AB}$ Mix solution is linear with the equation $=86.056+0.0676 \mathrm{~K}, \mathrm{r}=0.99$. The equation describes a positive linear relationship between the concentration of the AB Mix solution and the wet weight.

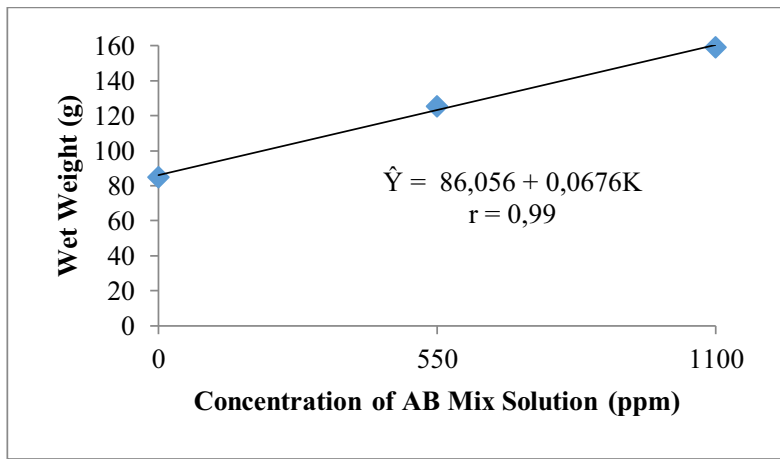

Fig.6. Relationship between Wet Weight (g) and Concentration of AB Mix Solution (ppm)

Giving ZPT had no significant effect on the wet weight of mustard greens. The heaviest wet weight was obtained in treatment $Z_{2}(1 \mathrm{ml})$ which was $141.33 \mathrm{~g}$, followed by treatment $Z_{1}(0.5 \mathrm{ml})$ which was $120.22 \mathrm{~g}$ and treatment $Z_{0}$ (control) was $108.11 \mathrm{~g}$.

Table 1. Average Effect of Concentration of AB Mix Solution and ZPT on Growth and Production of Mustard Plants (Brassica juncea $\mathrm{L}$ ) in Hydroponic Wick Systems

\begin{tabular}{|c|c|c|c|c|c|c|}
\hline Treatment & $\begin{array}{c}\text { Plant } \\
\text { Height }(\mathrm{cm})\end{array}$ & $\begin{array}{c}\text { Number of } \\
\text { Leaves } \\
\text { (sheet) }\end{array}$ & $\begin{array}{l}\text { Leaf } \\
\text { Length } \\
(\mathrm{cm})\end{array}$ & $\begin{array}{l}\text { Leaf } \\
\text { Width } \\
\text { (cm) }\end{array}$ & $\begin{array}{c}\text { Wet } \\
\text { Weight } \\
(\mathrm{g})\end{array}$ & $\begin{array}{c}\text { Dry } \\
\text { Weight } \\
\text { (g) }\end{array}$ \\
\hline $\begin{array}{c}\text { AB Mix Solution } \\
\mathrm{K}_{0} \\
\mathrm{~K}_{1} \\
\mathrm{~K}_{2}\end{array}$ & $\begin{array}{l}5,69 \mathrm{~b} \\
6,54 \mathrm{a} \\
7,18 \mathrm{a}\end{array}$ & $\begin{array}{l}8,39 \mathrm{~b} \\
9,00 \mathrm{a} \\
9,39 \mathrm{a}\end{array}$ & $\begin{array}{l}10,68 \mathrm{~b} \\
11,71 \mathrm{a} \\
12,61 \mathrm{a}\end{array}$ & $\begin{array}{r}8,46 \mathrm{~b} \\
10,43 \mathrm{a} \\
10,87 \mathrm{a}\end{array}$ & $\begin{array}{r}84,89 \mathrm{c} \\
125,55 \mathrm{~b} \\
159,22 \mathrm{a}\end{array}$ & $\begin{array}{r}6,56 \mathrm{c} \\
10,56 \mathrm{~b} \\
12,33 \mathrm{a}\end{array}$ \\
\hline $\begin{array}{c}\text { Giving of ZPT } \\
\mathrm{Z}_{0} \\
\mathrm{Z}_{1} \\
\mathrm{Z}_{2}\end{array}$ & $\begin{array}{l}6,32 \\
6,49 \\
6,59\end{array}$ & $\begin{array}{l}8,81 \\
8,89 \\
9,08\end{array}$ & $\begin{array}{l}11,02 \\
11,78 \\
12,19\end{array}$ & $\begin{array}{r}9,36 \mathrm{~b} \\
9,58 \mathrm{~b} \\
10,81 \mathrm{a}\end{array}$ & $\begin{array}{l}108,11 \\
120,22 \\
141,33\end{array}$ & $\begin{array}{r}8,55 \\
9,67 \\
11,22\end{array}$ \\
\hline $\begin{array}{c}\text { Interaction } \\
\mathrm{K}_{0} \mathrm{Z}_{0} \\
\mathrm{~K}_{0} \mathrm{Z}_{1} \\
\mathrm{~K}_{0} \mathrm{Z}_{2} \\
\mathrm{~K}_{1} \mathrm{Z}_{0} \\
\mathrm{~K}_{1} \mathrm{Z}_{1} \\
\mathrm{~K}_{1} \mathrm{Z}_{2} \\
\mathrm{~K}_{2} \mathrm{Z}_{0} \\
\mathrm{~K}_{2} \mathrm{Z}_{1} \\
\mathrm{~K}_{2} \mathrm{Z}_{2}\end{array}$ & $\begin{array}{l}6,20 \\
5,40 \\
5,47 \\
6,04 \\
6,73 \\
6,85 \\
6,73 \\
7,35 \\
7,46\end{array}$ & $\begin{array}{l}8,25 \\
8,25 \\
8,67 \\
8,92 \\
9,00 \\
9,08 \\
9,25 \\
9,42 \\
9,50\end{array}$ & $\begin{array}{r}9,84 \\
10,94 \\
11,25 \\
11,20 \\
11,92 \\
12,00 \\
12,03 \\
12,47 \\
13,33\end{array}$ & $\begin{array}{r}8,05 \\
8,31 \\
9,02 \\
9,86 \\
10,11 \\
11,32 \\
10,18 \\
10,33 \\
12,09\end{array}$ & $\begin{array}{r}60,00 \\
82,00 \\
112,67 \\
120,00 \\
127,33 \\
129,33 \\
144,33 \\
151,33 \\
182,00\end{array}$ & $\begin{array}{r}4,33 \\
6,67 \\
8,67 \\
10,00 \\
10,67 \\
11,00 \\
11,33 \\
11,67 \\
14,00\end{array}$ \\
\hline
\end{tabular}

Note: the numbers followed by letters that are not the same in the same treatment group are significantly different at $5 \%$ with the DMRT test 


\subsection{Dry Weight (g)}

The results of the analysis of variance show that the concentration of the AB Mix solution had a significant effect. The treatment of giving ZPT and the interaction of the two treatment factors had no significant effect on the dry weight of mustard greens. The average dry weight of mustard greens is presented in Table 1.

In Table 1 it can be seen that the concentration of the AB Mix solution had a significant effect on the dry weight of mustard greens. The heaviest dry weight was obtained in treatment K2 (1100 ppm) which was 12.33 $\mathrm{g}$, which was significantly different from treatment $\mathrm{K} 0$ (control) which was $10.56 \mathrm{~g}$ and treatment K1 (550 $\mathrm{ppm})$ which was $6.56 \mathrm{~g}$.

The relationship between dry weight of mustard greens and the concentration of $\mathrm{AB}$ Mix solution is linear with the equation $=6.927+0.0053 \mathrm{~K}, \mathrm{r}=0.97$. The equation describes a positive linear relationship between the concentration of the $\mathrm{AB}$ Mix solution and the dry weight.

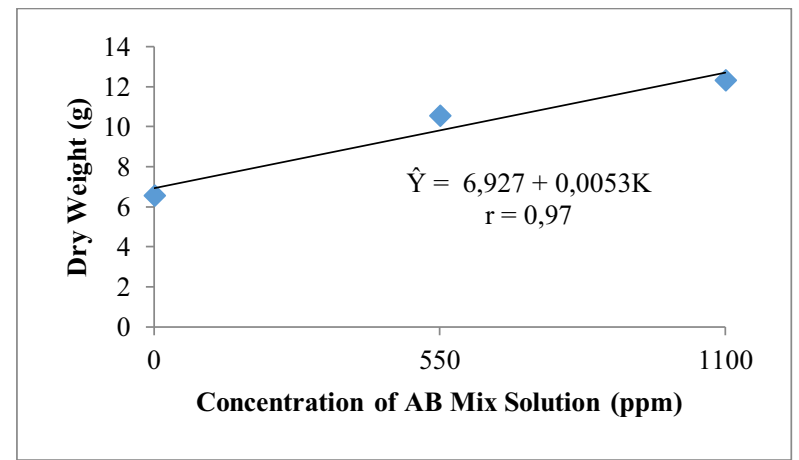

Fig.7. The Relationship of Mustard Dry Weight (g) with Provision of AB Mix Solution Concentration (ppm)

Giving of ZPT had no significant effect on the dry weight of mustard greens. The heaviest dry weight was obtained in treatment $Z_{2}(1 \mathrm{ml})$ which was $11.22 \mathrm{~g}$, followed by treatment $Z_{1}(0.5 \mathrm{ml})$ which was $9.67 \mathrm{~g}$ and treatment $Z_{0}$ (control) was $8.55 \mathrm{~g}$.

\section{Discussion}

\subsection{Effect of Concentration of AB Mix Solution on Growth and Production of Mustard Plants (Brassica juncea L) in Hydroponic Wick Systems}

The concentration of $\mathrm{AB}$ Mix solution significantly affected plant height, number of leaves, leaf width, leaf length, wet weight and dry weight.

Giving AB MIX ocean with a concentration of 1100 ppm significantly increased the concentration of the $A B$ Mix solution significantly affected plant height, number of leaves, leaf width, leaf length, wet weight and dry weight, with increasing concentration of the given solution from $0 \mathrm{ppm}, 550 \mathrm{ppm}$ and $1100 \mathrm{ppm}$ the increase in both growth and production of mustard greens. This is because the nutrient content in the $\mathrm{AB}$
Mix solution plays an important role in increasing growth and production.

The results showed that the treatment with the concentration of $\mathrm{AB}$ Mix $1100 \mathrm{ppm}$ (K2) gave the highest plant height, which was $7.18 \mathrm{~cm}$, this was related to giving the right concentration of $\mathrm{AB}$ Mix solution for mustard greens. According to Nugraha (2014) states that the composition of macro and micro nutrients is very influential on plants. Therefore, in the application of fertilizers, it must be balanced according to the needs of the plant [8].

The results showed that the concentration treatment of $\mathrm{AB}$ Mix $1100\left(\mathrm{~K}_{2}\right)$ solution gave the highest number of leaves, namely 9.39 strands. This is because the $\mathrm{AB}$ Mix solution is able to trigger the growth of the number of leaf stalks more than the $1200 \mathrm{ppm}$ treatment and the $1300 \mathrm{ppm}$ treatment used. Based on the difference in concentration which is considered sufficient in plant tissue, the higher the availability of plant nutrients, the higher the possibility of plant production if other factors also support it, if the availability of plant nutrients is large but other factors do not support the plant will not grow perfectly [9].

The results showed that the concentration treatment of $\mathrm{AB}$ Mix $1100\left(\mathrm{~K}_{2}\right)$ solution gave the highest leaf length of $12.61 \mathrm{~cm}$ and the highest leaf width of 10.87 $\mathrm{cm}$. This is because the AB Mix solution given is a concentration that suits the needs of plants, such as mustard greens grown with a hydroponic system. This opinion is in line with the results of research by Akasika et al., (2014), which states that the provision of nutrients with a concentration of $1000 \mathrm{ppm}$ will Accelerate the rate of leaf formation, because plants need nutrients, especially $\mathrm{N}$, which plays a major role in the vegetative phase have had enough. In plant vegetative growth as indicated by the increase in plant length, the nutrient that plays a role is nitrogen $(\mathrm{N})$ [10].

The results showed that the concentration treatment of AB Mix $1100\left(\mathrm{~K}_{2}\right)$ solution gave the highest wet weight of $159.22 \mathrm{~g}$. The increase in wet weight was related to other growth parameters such as plant height, number of leaves, roots and chlorophyll content. Suarsana et al., (2019) states that the rate of cell division and tissue formation is proportional to the growth of stems, leaves and root systems. This depends on the availability of carbohydrates in plants [11].

The results showed that the concentration treatment of AB Mix 1100 (K2) solution gave the highest dry weight of $12.33 \mathrm{~g}$. Dry weight decreased with increasing nutrient concentration. This dry weight loss showed no signs of toxicity. The most likely thing is that increasing the concentration of nutrients will also increase the availability and absorption of $\mathrm{N}$ and $\mathrm{K}$ elements, where these two elements play a very important role in regulating cell turgor and succulence of plant organs [12]. Succulent plants usually have high fresh weight but low dry weight due to the high water content in their organs. 


\subsection{Effect of Concentration of ZPT on Growth and Production of Mustard Plants (Brassica juncea $L$ ) in Hydroponic Wick Systems}

Giving ZPT had a significant effect on leaf width, but had no significant effect on plant height, number of leaves, leaf length, wet weight and dry weight.

The best ZPT treatment was obtained at a concentration of $1 \mathrm{ml}$. Increasing the concentration of PGR significantly increased leaf width. This increase was caused by the hormone content in the ZPT, resulting in a process of elongation of new cells and eventually increasing the amount of tissue in plants resulting in faster plant growth. This is in line with Djamhari (2010) who explained that the application of exogenous ZPT in plants can function to stimulate the formation of phytohormones, so that they can encourage a biochemical activity. Phytohormones as organic compounds that work actively in small amounts are usually transformed throughout the plant so that they can affect plant growth or physiological processes [13].

Provision of ZPT had no significant effect on plant height, leaf length, wet weight and dry weight. According to Ardiana (2009), in an in vitro experiment, it was stated that giving ZPT with a concentration of $\mathrm{ppm}$ gave the best results, however, if the PGR concentration was increased to $1-1 \frac{1}{2} \mathrm{ppm}$, plant growth would be stunted [14]. According to Suyanti et al., (2013), cytokinins can inhibit the initiation and growth of lateral roots (lateral root primordium) but the mechanism of inhibitory regulation of these compounds is not known with certainty [15]. This is in accordance with the results obtained where the lowest results were in the ZPT treatment with a concentration of $0.5 \mathrm{ml}$ even though the results were still higher than the control.

Giving ZPT did not significantly affect the number of leaves. This was indicated by the addition of higher ZPT which did not increase the number of leaves. These results are supported by research conducted by Widiastoety (2014), who wrote that excessive cytokinin concentrations resulted in inhibition of shoot differentiation and growth, in addition to in vitro studies showing that often the use of cytokinins can stimulate the biosynthesis of ethylene compounds which causes inhibition of shoot growth, inhibits cell division. and cell elongation which results in the absence of other organs [16].

Cytokinins play a role in slowing plant aging. However, an increase in cytokinin content will inhibit shoot growth, reduce the accumulation of total chlorophyll, and delay the induction of flowering [17]. In a study conducted by Handayani et al., (2020), there was an increase in the number of cytokinins during the aging process, so that the yellowing process in plants was delayed. This is related to chlorophyll-degrading enzymes such as chlorophyllase, Mg-dechlatase, and peroxidase, where these three enzymes will increase their activity by ethylene while cytokinins decrease it [18]. This statement is in accordance with the results obtained where the addition of ZPT with a concentration of $0.5 \mathrm{ml}$ is not much different from the treatment of giving ZPT with a concentration of $1 \mathrm{ml}$.

\subsection{Effect of Concentration of AB Mix Solution and ZPT on Growth and Production of Mustard Plants (Brassica juncea $L$ ) in Hydroponic Wick Systems}

The interaction of giving the concentration of $\mathrm{AB}$ Mix solution and ZPT had no significant effect on the growth and production of mustard greens (Brassica juncea L.) in the Hydroponic Wick system.

Although it had no significant effect, the two factors interacted positively to increase the growth and production of mustard greens. Giving AB Mix solution with ZPT will support each other. This is because the availability of nutrients greatly affects the growth and development of plants, especially $\mathrm{N}$ for mustard plants. According to Gardner et al., (1991) in Zamriyeti et al., (2019) the essential function of nitrogen nutrients in plant tissue is cell division and enlargement [19].

\section{Conclusion}

The concentration of $\mathrm{AB}$ Mix solution significantly affected plant height, number of leaves, leaf width, leaf length, wet weight and dry weight mustard plants. The best concentration of $\mathrm{AB}$ Mix solution was in the $\mathrm{K}_{2}$ (1100 ppm) treatment with a plant height of $7.18 \mathrm{~cm}$, leaf number 9.39 , leaf width $10.87 \mathrm{~cm}$, leaf length 12.61 $\mathrm{cm}$, wet weight $159.22 \mathrm{~g}$ and dry weight $2.33 \mathrm{~g}$.

Giving ZPT had a significant effect on leaf width, but had no significant effect on plant height, number of leaves, leaf length, wet weight and dry weight mustard plants. The best ZPT treatment was given to $Z_{2}(1 \mathrm{ml})$ with a leaf width of $10.87 \mathrm{~cm}$, plant height $6.59 \mathrm{~cm}$, leaf number 9.08 , leaf length $12.19 \mathrm{~cm}$, wet weight $141.33 \mathrm{~g}$ and dry weight $11,22 \mathrm{~g}$. The interaction of the concentration of the $\mathrm{AB}$ Mix solution and the addition of ZPT had no significant effect on the growth and production of mustard plants.

\section{References}

1. A. Fuad, Budidaya tanaman sawi (Brassica juncea L.) (Skripsi, Universitas Sebelas Maret Surakarta, 2010)

2. Badan Pusat Statistik. Statistik Tanaman Hortikultura Indonesia.http:www.bps.go.id.

3. A. D. Susila, Sistem Hidroponik (Departemen Agronomi dan Hortikultura, Fakultas Pertanian, Institut Pertanian Bogor, 2013)

4. H. Sunarjono, Bertanam Sawi dan Selada (Penebar Swadaya, Jakarta, 2014)

5. S. Cahyo dan S. Rini, Panduan Lengkap Budidaya Ikan dan Sayuran Dengan Sistem Aquaponik (Yogyakarta, Lily Publisher, 2014)

6. Y. Nurlaeni dan M.I. Surya, Pros Sem Nas Masy Biodiv Indon 1, 5 (2015)

7. M. Dwiati, Peran Zat Pengatur Tumbuh Auksin Dan Sitokinin Terhadap Pertumbuhan Semai Anggrek Phalaenopsis (Fakultas Biologi Unsoed, Banteran, 2016) 
8. R. U. Nugraha, Sumber Hara Sebagai Pengganti AB Mix pada Budidaya Sayuran Daun Secara Hidroponik (Departemen Agronomi dan Holtikultura, Institut Pertanian Bogor, 2014)

9. H. Fitriani, Iskandar M. Lapanjang Ramal Yusuf. Respon Pertumbuhan Tanaman Sawi (Brassica juncea L.) Secara Hidroponik Terhadap Komposisi Media Tanam dan Konsentrasi Pupuk Organik Cair (Program Studi Agroteknologi Fakultas Pertanian Universitas Tadulako, Palu, 2015)

10. R. Akasika, Samekto dan Siswadi, J. Inov. Pertan, 13, 2 (2014)

11. M. Suarsana, I. P. Parmila, K. A. Gunawan, Agro Bali (Agricultural J.) 2, 2 (2019)

12. M. N. Subandi, Purnama dan B, Frasetya, J. Agroekoteknologi UIN Sunan Gunung Djati Bandung 9, 2 (2015)

13. S. J. Djamhari S, J, Sains dan Teknologi Indonesia 12, 1 (2010)

14. D. W. Ardiana, Buletin Teknik Pertanian 14, 2 (2009)

15. Suyanti, Mukarlina, Rizalinda, Protobiont 2, 2 (2013)

16. D. Widiastoety, J. Hort 24, 3 (2014)

17. E. Mutryarny, J. Ilmiah Pertan 14, 2 (2018)

18. K. P. Handayani, Safruddin, S., Hasibuan, S. Bernas 15, 1 (2020)

19. M. Zamriyetti, Siregar, Refnizuida. Agrium, J. Ilmu Pertan 22, 1 (2019) 